\title{
THE QUALITY MODEL ORGANIZATIONAL CULTURE ASSESSMENT INSTRUMENT (OCAI)
}

\author{
Yuni Pratikno ${ }^{1}$, Maulana Arief Rachman Hakim ${ }^{2}$, Indi Nervilia ${ }^{3}$, Jujuk Kusumawati ${ }^{4}$, Wynd \\ Rizaldy $^{5}$, Munir Azhari ${ }^{6}$, Lindawati ${ }^{7}$ and Eko Cahyo Mayndarto ${ }^{8}$ \\ 1,2,3, 6,7 Department of Management, IMMI School of Management, Jakarta, Indonesia \\ ${ }^{4}$ Department of Civil Engineering, ITBU, Jakarta, Indonesia \\ ${ }^{5}$ Department of Logistic Management, ITL Trisakti, Jakarta, Indonesia \\ ${ }^{8}$ Department of Accounting, Tama Jagakarsa University, Jakarta, Indonesia \\ yuni.pratikno@gmail.com
}

\begin{abstract}
Organisational culture is a system of shared beliefs and values in the organisation and directs its members' behaviour. There are various factors of change that influence organisational culture; various things are done to anticipate changes in the shift from the present situation to the desired conditions in a sustainable change. On the one hand, change occurs because of external factors that encourage change; on the other hand, change is an internal need. Change can be interpreted as absolute and unavoidable because of the strong external impulse and internal needs.
\end{abstract}

This research carried out at PT Briscor Horizon in 2020. This research was qualitative, namely research that intends to understand the phenomenon of what is experienced by the research subject holistic, and by way of description in the form of words and language, in a particular natural context and by utilising various natural methods. Data collection techniques used by researchers are interviews, documentation, and field observations.

\section{Keyword: Implementation, Organizational} Culture, OCAI Model

\section{Introduction}

PT. Briscor Horizon, an accommodation service management company with the Brand Rukun Senior Living, Rukun Senior Care, Rukun Home Care, Olé! Suites Hotel, and Olé! Suites \& Cottage, has been implementing the ISO 9001: 2008 quality management system for a long time and upgraded to the ISO 9001: 2015 version. On the other hand, the company has also implemented an occupational health and safety management system (SMK3) which refers to OHSAS 18001: 2007 Occupational Health and Safety Management Systems. It shows the company's commitment to providing added value for all company shareholders to measure its performance achievement in winning the competition.

PT. Briscor Horizon has a culture called COCOTEFASERA, which consists of Communication, Competence, Teamwork, Fairness, Self Control, and Rationality. Communication culture regulates how to communicate in the work environment openly (open), directly (direct) both vertically (superiors - subordinates) and horizontally (colleagues) delivered in an informal or formal direction. Competence culture requires that every employee continuously improve his/her competence at work which consists of skills, knowledge, and attitudes. Teamwork culture regulates that every employee must work in a team with an understanding of interdependence and unity. Fairness regulates how decisions are made based on the majority's perception; all have the same right to develop and respect each other. Self-Control regulates that every employee can control themselves through supervisory supervision replaced by self-supervision, separating personal and work matters, having selfawareness or discipline, distinguishing good and bad, always not arrogant and introspective, and carrying out the trust given. Rationality teaches that expressing facts must be based on factual data, logical and consistent in opinion, always cool-headed in solving problems, and open-minded.

Based on the description above, the problems faced by PT Briscor Horizon identified as follows: (1) Communication as a culture has not been going well with communication barriers either directly, vertically (superiors- subordinates) or horizontally (colleagues) work so that it can hinder work; (2) Competence as a culture is still not up to expectations, especially in improving performance in the form of improvements made in each department; (3) Self-control is still not reflected as a culture in every job, especially regarding work discipline; (4) Measurement through Peer Assessment cannot 
reflect actual conditions so that management has not been able to make accurate decisions concerning work culture improvement and development programs; (5) The measurement of understanding and implementation of work culture has not carried out using other methods besides Peer Assessment; (6) Employee improvement and development programs have not been able to improve understanding and implementation of work culture effectively; (7) The employee's long tenure does not necessarily reflect the understanding and implementation of good work culture following company expectations; (8) The addition of new employees can be a potential shift in values regarding work culture; and (9) There are still differences in employee understanding of work culture.

Based on identifying existing problems, the authors focus on research: (1) How is the communication level (Communication) of employees as an organizational culture at PT Briscor Horizon? (2) How is the competence level (Competence) of employees as an organizational culture at PT Briscor Horizon? and (3) How is the level of employee selfcontrol as an organizational culture at PT. Briscor Horizon?

\section{Literature Review}

\section{Communication}

Communication occurs when there is a similarity in meaning regarding a message conveyed by the communicator and received by the communicant (Effendi, 2016). Communication defined as the process of transferring messages via means or media of communication to the intended communicant. According to Hovland "Communication is the process to the modify the behaviour of other individuals" communication is the process of changing other people's behaviour (Effendi, 2004: 10). Everett M. Rogers, a sociologist who has much attention to communication research, especially in terms of spreading innovation, defines that: "Communication is the process by which an idea is transferred from the source to one or more recipients, to change their behaviour" (Cangara, 2002). This definition was then developed again by Rogers with D. Lawrence Kincaid with a new definition which states that: "Communication is a process in which two or more people form or exchange information with each other, which in turn will arrive at a deep mutual understanding" (Cangara, 2002). According to Januar Darmawan, communication is a systematic information exchange process between one party and another which usually uses the same symbol system.

Communication must be built based on top-down initiatives, both vertically and horizontally, must be open and direct, and have the character of increasing informal communication and reducing the formal portion (Andrias Harefa, 2008). The process of delivering messages from communicators to communicants through certain media to produce effects/goals by expecting feedback or feedback. Delivery of messages can be in the form of ideas and hopes conveyed through symbols to the public (Cordell et al., 2019).

Based on this definition, the researcher synthesizes that communication can change a person's attitudes, opinions, and behaviour. Communication is the process of conveying ideas, hopes and messages conveyed through certain symbols, contained meaning and carried out by the messenger and aimed at the recipient of the message.

\section{Competence}

(Nagy, 2005) states that competence is the ability to carry out or perform a job or task based on skills and knowledge and supported by the work attitude required by the job. Thus, competence shows skills or knowledge characterized by professionalism in a particular field as the most critical thing, superior in specific fields. Meanwhile, (Marwansyah, 2012) states that competence is an ability, skill, ability. The root word itself is competent, which means competent, capable, skilled. Competence refers to the attributes/characteristics of a person that make one's success in the job.

According to (Le Deist \& Winterton, 2005), competency comes from English competency, which means proficiency, ability and authority. So competence is a performance that leads to the complete achievement of goals towards the conditions they want. (Dean, 2017) also states that core competence is the principal value of a company/organization in creating skills and capabilities that spread through various production or business lines.

According to Januar Darmawan in his book "Sustainable Growth" written by (Andrias Harefa, 2008), it can be said that, in general, competence is one of the building blocks of trust, competence is the ability to carry out and complete tasks and responsibilities today and for the future, and proactively seek and share knowledge in supporting personal growth.

Five essential competencies are considered critical: motivation, personal uniqueness, self-concept, knowledge, and skills. Knowledge and skills are visible and easily recognizable competencies that serve as a competency threshold. Meanwhile, motivation, personal uniqueness and self-concept are more hidden and function as differentiates competency. Referring to the definitions above could be synthesized that competence is an ability a person must have, especially employees, to reach the professional employee level based on skills and knowledge and supported by their work attitude. 


\section{Self Control}

According to (Chaplin, 2014), self-control is the ability to guide one's behaviour, the ability to suppress or block impulses or impulsive behaviour. Self-control involves how strongly a person holds values and beliefs to be used as a reference when he acts or makes decision. (M. Nur Ghufron \& Rini Risnawita S, 2014) define self-control as regulating a person's physical, psychological, and behavioural processes, in other words, a series of processes that shape themselves. Self-control is an ability to organize, guide, regulate, and direct forms of behaviour that can positively affect individuals. Selfcontrol also describes individual decisions through cognitive considerations to unify behaviours structured to improve specific outcomes and goals as desired (M. Nur Ghufron \& Rini Risnawita S, 2014).

According to (Chambers, 2005), self-control is a complete link made by individuals to their environment. Individuals with high self-control are concerned about the proper ways to behave in a variety of situations. Individuals tend to change their behaviour following the demands of social situations which can then set the impression that their behaviour is made more responsive to situational cues, more flexible, tries to facilitate social interaction, is warm, and open.

According to Januar Darmawan, Self-Control is awareness of oneself to behave, act and work to achieve company goals. A good leader can build selfcontrol in its members (Andrias Harefa, 2008). It would be more beneficial to have a team that can build internal responsibility to keep promises, complete work on time, take the initiative, be creative, and innovate to achieve progress from day to day (MacLean et al., 2014).

From the description above, it can be synthesized that self-control controls behaviour and thought patterns before taking an action. Controlling behaviour implies that it is to make considerations before deciding on something to act. The higher a person's self-control, the more often the control over behaviour will be. Low self-control will make a person more susceptible to impulsive behaviour, insensitivity, taking risks, and a marked tendency.

\section{Analysis Model}

The type of effective organisation divided into two dimensions: distinguishing effectiveness criteria that emphasise flexibility, discretion, and dynamism with dimensions that emphasise stability, orders, and control. These two types form four quadrants, as shown in Figure 1, where each quadrant describes various indicators of organisational effectiveness. These four groups can provide an overview of people's assessment of organisational performance, the definition of what looks reasonable, actual, and appropriate; in other words, defining the core values for conducting organisational assessments.

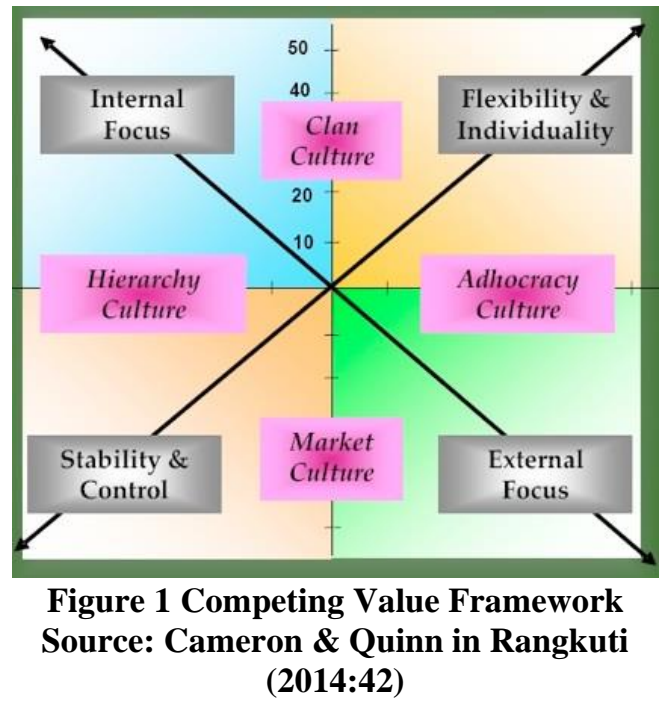

(Sánchez-Cañizares et al., 2007) explained a measurement model and diagnosis of organizational culture based on a competing value framework which divides into four types with the respective criteria according to as follows.

First, Clan Culture. This type of culture is in the upper left quadrant, as shown in Figure 1. This type of culture called a clan because it is almost the same as the type of organization, kinship, which is one of the ideal types of culture. The clan culture emphasizes flexibility and discretion rather than stability and integration; the work environment is open and friendly, allowing everyone to interact and share. The organization managed like an extended family. Leaders are considered mentors and even parents. Adherence to organization and tradition is relatively strong. Emphasizes long-term human resource development and group cohesiveness. The focus of attention is on people and values teamwork, participation, and consensus. This type of culture is more familial than an economic institution.

Clan culture prioritizes teamwork, staff involvement in programs and a company commitment to employees with basic assumptions that the environment managed well through teamwork, employee development and customers positioned as partners. Organizational development of various work environments and management's main task is to strengthen employees and facilitate employee participation in the company, commitment, and loyalty. Shared values, goals, cohesion, participation, individuality, and a perspective that is only selforiented have fused into this type of culture. When the organization must face changes in the fast and robust environment, it is difficult for leaders to make plans that are far ahead and decisions uncertain. The most effective way is to make certain that all 
company employees have the same values, beliefs, and goals to be achieved.

Secondly, Adhocracy Culture. One of the ideal culture types that emerged after the industrialisation change to the information age is the adhocracy culture type. This type of culture emphasises that innovation and recent discoveries are the keys to an organisation's success, often found in dynamic industrial companies, such as software development and information technology.

The meaning of adhocracy rooted from ad hoc, states something temporary, unique, and dynamic. In this type of culture, the organization can change rapidly according to environmental changes with the primary objective of encouraging adaptation, flexibility, and creativity when uncertainty, ambiguity, and information overload arise. Adhocracy culture is similar to a clan culture in emphasizing flexibility and discretion. In contrast, adhocracy culture focused on external organizations and differentiation.

The characteristics of this type of culture are shown by a dynamic, entrepreneurial and creative work environment, organizational members are brave enough to face risks, influential leaders are leaders who have a vision, innovation and are risk-oriented with the adhesive of an organization's commitment to experiment and innovation. The adhocracy-type culture emphasizes the success of being the forerunners of the latest knowledge, products, and services. Readiness to face change and face new challenges is essential in this type of culture. The organization's long-term emphasis is on achieving rapid growth. Success means producing products and services that are distinctive and genuine.

Thirdly, Market Culture. The ideal type of culture popular in the late 1960s when organizations faced new competitive challenges with transaction costs was an essential thing in organizational effectiveness. Market culture has similarities with hierarchical cultures, especially in terms of prioritizing stability and control. The difference is that market culture focuses on external aspects and differentiation. Market culture focuses on relationships and transactions with suppliers, customers, contractors, legislators, consultants and regulators. Focus on the external aspects of the organization is believed to bring the organization to success. On the other hand, hierarchy and control exercised through regulations, standard operating procedures, and highly specialized jobs.

Human resource management is results-oriented and competitive. Leaders are demanding and motivating and productive people. The emphasis on winning becomes the goal that unites the members of the organization. Focus attention on success and reputation. The long-term orientation is on competitive actions and the achievement of organizational goals and targets. Success defined as dominating market share and penetration, emphasizing competitive prices and market leadership.

This type of market culture is more oriented towards the external environment than the environment within the organization. This type of culture focuses more on relationships (transactions), especially in institutions outside the organization, such as suppliers, customers, contractors, licensors, and the government. Internal control, in this type of culture, market firms depend on market economic mechanisms, particularly on the exchange rate of money. The core values in this culture are competitiveness and productivity.

Fourthly, Hierarchy Culture. Hierarchical organizations usually characterized by a bureaucracy with a culture that prioritizes stability and control and focuses on internal processes and integration. Organizations with a hierarchical culture emphasize standardization, control, and a standard and firm structure for regulatory authority and decision making.

Working environments organised in a very structured and formal manner, and rules and procedures regulate organisational members' attitudes and behaviour. Leaders are required to be coordinators and managers with an efficiency mindset and approach. Keeping the organisation running well is the most crucial task. Formal policies serve as guidelines that must be understood, adhered to and implemented by all organisation members. The long-term orientation emphasises stability, efficient operation, and performance. Success defined as the ability to deliver quality products and services on the proper schedule at low cost. Management wants everything to be predictable and run safely to refer to stability, efficiency, and high consistency in products and services. Because the environment was relatively stable, functions and tasks could be integrated and coordinated easily, uniformity in products and services was well controlled, workers and their work were under close supervision. Apparent decisionmaking authority, standardised rules and procedures for oversight and accountability mechanisms are values that are successful in hierarchical type organisations.

Six questions define the cultural dimension to determine the organisation's culture in the Organizational Culture Assessment Instrument (OCAI), namely: (1) Dominant characteristics are characteristics that describe the overall organisational culture; (2) Organisational leadership is a style and approach to leadership that permeates the organisation; (3) Human resource management (management of employees) is a style that 
characterises the organisation in treating its workers and describes the work environment; (4) The organisational adhesive is a bonding mechanism that makes the organisation become one unit; (5) Emphasis on strategy (strategic emphasis) shows the areas that become the emphasis in the organisation; and (6) Success criteria (criteria of success) show the benchmarks for the organisation's success/failure in carrying out its activities.

Organizational Culture Assessment Instrument (OCAI) helps identify the current culture and help members of the organization identify the culture that must be developed to face future environmental demands and various things that the organization may face. This instrument used to recognize the dominant culture (cultural strength), the types of culture that exist (cultural type), and the suitability of the culture (cultural congruence).

There are six advantages to diagnosing using OCAI. First, practical. This instrument can identify the critical dimensions of culture found to make a difference in organisational success. Secondly, timely. The process from diagnosis and strategy creation to change, completed within a reasonable amount of time, Thirdly, involving. Every step in this process involves all organisation members, especially those who have the responsibility of developing direction, strengthening values, and developing guidelines for fundamental change. Fourthly, quantitative and qualitative. This process based on quantitative measurements of critical dimensions of culture and qualitative methods, including history, events, and symbols representing immeasurable values in the organisation. Fifthly, manageable. The diagnosis and change process can be carried out and implemented by the team in the organisation, usually the management team. Outside diagnosis, cultural experts, or consultants not required for a successful implementation. Sixthly, valid. The framework in this process built to be understood by the owner and supported by complete empirical literature and dimensions that have a verified scientific basis.

In conducting the research, the writer made a conceptual research framework that started with environmental changes that affected the organisation's culture and would implement organisational culture based on the organisational culture assessment instrument (OCAI) at PT Briscor Horizon. So that the current organisational culture conditions and conditions expected by management will be known, where the authors analyse then can provide conclusions and suggestions for management, as shown in Figure 2.

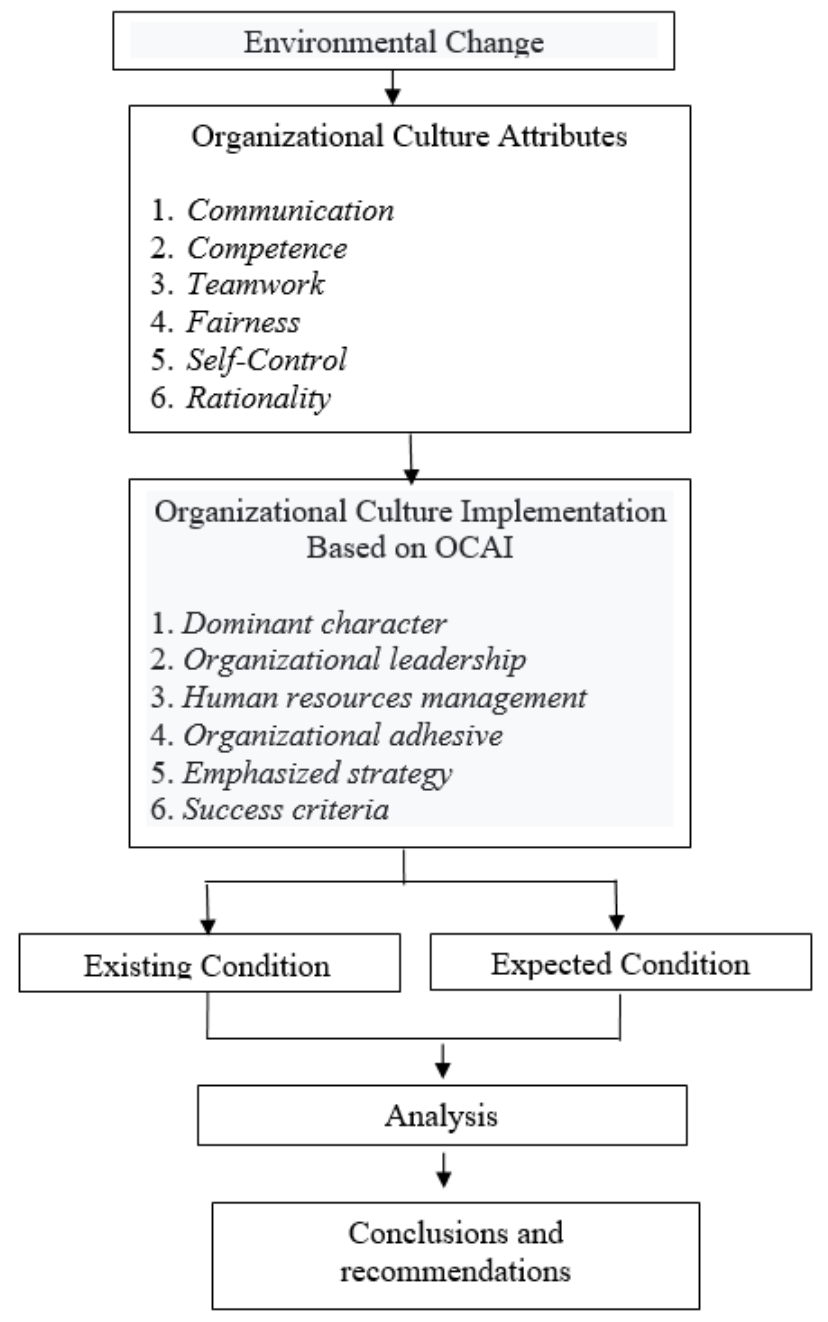

Figure 2 Research Concept Framework

\section{Research Method}

This type of research is non-causality - comparative research, which does not directly explain the causal relationship but compares several situations. On that basis, an assumption made from what causes the situation's difference (Sugiyono., 2013). (Arikunto, 2010), argues that "research methods are the various ways that researchers collect research data". The method referred to is an interview and documentation study. Data collection methods used in this study include interviews, documentation, and observation of informants. Informants are selected based on indepth knowledge of the organizational culture or who experience themselves. Based on these considerations, ten informants selected, including the Managing Director, General Manager, Manager/Department Head, and Supervisor/Coordinator.

The data analysis technique used in this research used the steps proposed by (Bungin, 2011), namely: (1) Data collection. Data collection is an integral part of data analysis activities that used interviews and documentation studies; (2) Data reduction, defined as the selection process, focusing on simplifying and 
transforming raw data that emerged from written records in the field. The reduction carried out since data collection begins by summarizing, coding, searching for themes, creating clusters, writing memos, and setting aside irrelevant data/information; (3) Data display is a description of a group of structured information that provides the possibility of drawing conclusions and taking action; (4) Conclusion drawing and verification is the last activity of data analysis. Furthermore, the analyzed data is explained and interpreted to describe the facts, meaning, or to answer research questions.

\section{Results}

Based on the selected model, the author analyzed the organizational culture of COCOTEFASERA through sub-focus research, namely Communication,
Competence, and Self Control, from the following scoring results.

\section{Communication}

The questionnaire scoring on communication aspect showed that: (1) the dominant characteristics reached 205,00 with a current average value of 20,50; (2) organisational leadership with a total value of 195,00 and an average value of 19,50 ; (3) the criteria for management in human resource management only reached 135,00 with an average of 13,50 ; (4) the criteria for organisational adhesive in communicating reached 145,00 with an average value of 14,50; (5) the criteria for strategic emphasis reached 170,00 with an average value of 17,00 ; and (6) success criteria in achieving the company's goals showed the total value of 150,00 with an average of 15,00 as depicted in table 1 .

Table 1 Current Communication Culture Scoring Results with the OCAI Model

\begin{tabular}{|l|l|l|}
\hline Communication Character & Current Score & Average Score \\
\hline Dominant characteristics & 205,00 & 20,50 \\
\hline Organisational leadership & 195,00 & 19,50 \\
\hline Human resource management & 135,00 & 13,50 \\
\hline Organisational adhesive & 145,00 & 14,50 \\
\hline Strategic emphasis & 170,00 & 17,00 \\
\hline Success criteria & 150,00 & 15,00 \\
\hline
\end{tabular}

Based on these results, it known that the character of the company's communication culture from the highest to the lowest value were: (1) dominant characteristics, (2) organizational leadership, (3) strategic emphasis, (4) success criteria, (5) human resource management, and (6) organizational adhesive.

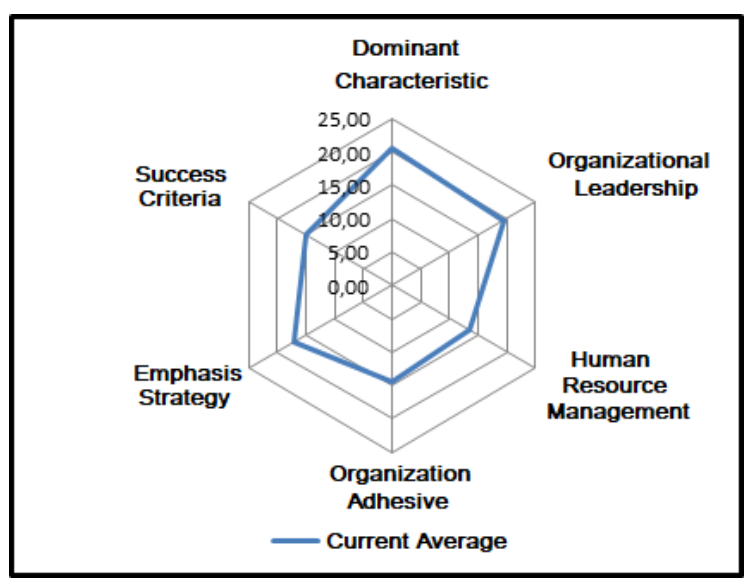

Figure 3 Current Communication Culture Scoring Analysis Results with the OCAI Model

\section{Competence}

The questionnaire scoring on competence aspect showed that: (1) the dominant characteristics reached 165,00 with a current average value of 16,50 ; (2) organisational leadership with a total value of 145,00 and an average value of 14,50 ; (3) the criteria for management in human resource management only reached 140,00 with an average of 14,00 ; (4) the criteria for organisational adhesive in communicating reached 145,00 with an average value of 14,50; (5) the criteria for strategic emphasis reached 210,00 with an average value of 21,00 ; and (6) success criteria in achieving the company's goals showed the total value of 195,00 with an average of 19,50 as depicted in table 2.

\section{Table 2 Current Competence Culture Scoring} Results with the OCAI Model

\begin{tabular}{|l|l|l|}
\hline Competence Character & $\begin{array}{l}\text { Current } \\
\text { Score }\end{array}$ & $\begin{array}{l}\text { Average } \\
\text { Score }\end{array}$ \\
\hline Dominant characteristics & 165,00 & 16,50 \\
\hline Organisational leadership & 145,00 & 14,50 \\
\hline Human resource management & 140,00 & 14,00 \\
\hline Organisational adhesive & 145,00 & 14,50 \\
\hline Strategic emphasis & 210,00 & 21,00 \\
\hline Success criteria & 195,00 & 19,50 \\
\hline
\end{tabular}


Based on these results, it known that the character of the company's communication culture from the highest to the lowest value were: (1) strategic emphasis, (2) success criteria, (3) dominant characteristics, (4) organizational leadership and (5) organizational adhesive, and (6) human resource management.

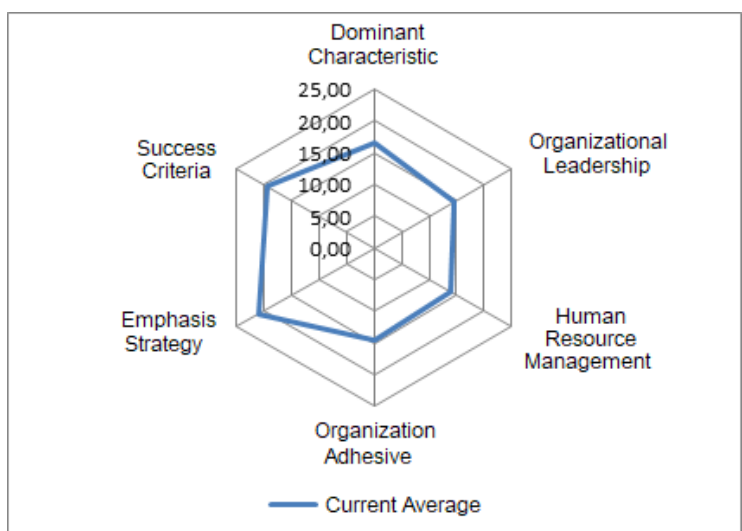

Figure 4 Current Competence Culture Scoring Analysis Results with the OCAI Model

\section{Self-Control}

The questionnaire scoring on self-control aspect showed that: (1) the dominant characteristics reached 210,00 with a current average value of 21,00 ; (2) organisational leadership with a total value of 185,00 and an average value of 18,50 ; (3) the criteria for management in human resource management reached 145,00 with an average of 14,50 ; (4) the criteria for organisational adhesive in communicating reached 135,00 with an average value of 13,50 ; (5) the criteria for strategic emphasis reached 175,00 with an average value of 17,50 ; and (6) success criteria in achieving the company's goals showed the total value of 150,00 with an average of 15,00 as depicted in table 3 .

Table 3 Current Self Control Culture Scoring Results with the OCAI Model

\begin{tabular}{|l|l|l|}
\hline Self-Control Character & $\begin{array}{l}\text { Current } \\
\text { Score }\end{array}$ & $\begin{array}{l}\text { Average } \\
\text { Score }\end{array}$ \\
\hline Dominant characteristics & 210,00 & 21,00 \\
\hline Organisational leadership & 185,00 & 18,50 \\
\hline $\begin{array}{l}\text { Human resource } \\
\text { management }\end{array}$ & 145,00 & 14,50 \\
\hline Organisational adhesive & 135,00 & 13,50 \\
\hline Strategic emphasis & 175,00 & 17,50 \\
\hline Success criteria & 150,00 & 15,00 \\
\hline
\end{tabular}

Based on these results, it known that the character of the company's communication culture from the highest to the lowest value were: (1) dominant characteristics, (2) organizational leadership, (3) strategic emphasis, (4) success criteria, (5) human resource management, and (6) organizational adhesive,

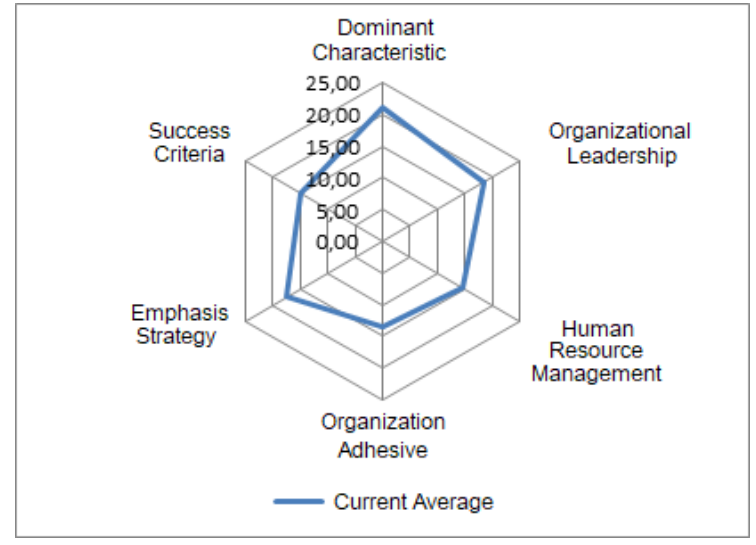

Figure 5 Current Self Control Culture Scoring Analysis Results with the OCAI Model

\section{Discussion}

From the research results described above, the research results interpretation are as follows.

\section{Communication}

The following table describes the questionnaire result on the communication culture sub-focus.

\begin{tabular}{|l|l|l|l|l|l|}
\hline $\begin{array}{l}\text { Communication } \\
\text { Character }\end{array}$ & $\begin{array}{l}\text { Current } \\
\text { Score }\end{array}$ & $\begin{array}{l}\text { Expected } \\
\text { Score }\end{array}$ & $\begin{array}{l}\text { Average } \\
\text { Current } \\
\text { Score }\end{array}$ & $\begin{array}{l}\text { Average } \\
\text { Expected } \\
\text { Score }\end{array}$ & $\begin{array}{l}\text { Average } \\
\text { Deviation }\end{array}$ \\
\hline $\begin{array}{l}\text { Dominant } \\
\text { characteristics }\end{array}$ & 205,00 & 175,00 & 20,50 & 17,50 & $-3,00$ \\
\hline $\begin{array}{l}\text { Organisational } \\
\text { leadership }\end{array}$ & 195,00 & 170,00 & 19,50 & 17,00 & $-2,50$ \\
\hline $\begin{array}{l}\text { Human resource } \\
\text { management }\end{array}$ & 135,00 & 175,00 & 13,50 & 17,50 & 4,00 \\
\hline $\begin{array}{l}\text { Organisational } \\
\text { adhesive }\end{array}$ & 145,00 & 190,00 & 14,50 & 19,00 & 4,50 \\
\hline $\begin{array}{l}\text { Strategic } \\
\text { emphasis }\end{array}$ & 170,00 & 150,00 & 17,00 & 15,00 & $-2,00$ \\
\hline Success criteria & 150,00 & 140,00 & 15,00 & 14,00 & $-1,00$ \\
\hline
\end{tabular}

\section{Table 4 Scoring Result of the Communication} Culture Value with the OCAI Model

In the sub-focus of communication culture, it could be seen that the total values of the dominant characteristics reached 205,00 with the current average value of 20,50 and the expected number of 175,00 with an average of 17,5. The average deviation difference of $-3,0$ indicates that the informants wanted a shift to decrease the leader's intensity or pressure of dominant communication; so bottom-up communication could be more intense, though this domination was because the leader job was to convey or send information or directions.

Organizational leadership total value was 195,00, with an average score of 19,50 , while the expected total value was 170,00 , with an average of 17,00 and a difference of $-2,5$. Like the dominant character, in the current organizational leadership, the communication was dominated by leaders where the communication is one-way down or top-down. In this regard, the informants wanted a decrease of the intensity so that two-way communication was 
horizontal and vertical, open, and direct, because they felt the possibility of feeling uneasy, or there was fear from subordinates.

The total value of the human resource management criteria was 135,00 , with an average of 13,50 , the total expected value was 175,00 , with an average of 17,5 and a deviation of 4,00 . It could be seen from the deviation that the informant wanted more attention to develop human resource management communication.

Like HR management, organisational adhesive criteria in communicating achieved a low number - a current total value of 145,00 with an average of 14,50 , the expected value of 190,00 and the expected average of 19,00 , and the average deviation 4,50 . The informants wanted more intense communication to be able to bond employees or organisational elements. This communication could be done through events and informal discussions held consistently.

The strategic emphasis criteria reached 170,00 with an average value of 17,00 , the total expected value of 150.00 and the average of 15.00 , and the average deviation of -2.00 . In this regard, the informants felt that it was better to slightly diverted attention to human resource management and bond employees.

The last, success criteria in achieving company's goals showed: (1) total value of 150.00 with an average of 15.00 , (2) the expected value of 140.00 and expected average of 14.00, and (3) average deviation of 1,00. Like the strategy emphasis, there was a decrease in intensity. After the strategy of achievement or goal was communicated to the leader through a balanced scorecard and cascaded to an action plan, informants also wanted attention in submitting it to the subordinate level. There was a need for continued motivation and socialized the company goals to all levels.

The scoring and interpretation results of the subfocus of communication culture are as illustrated in the following diagram.

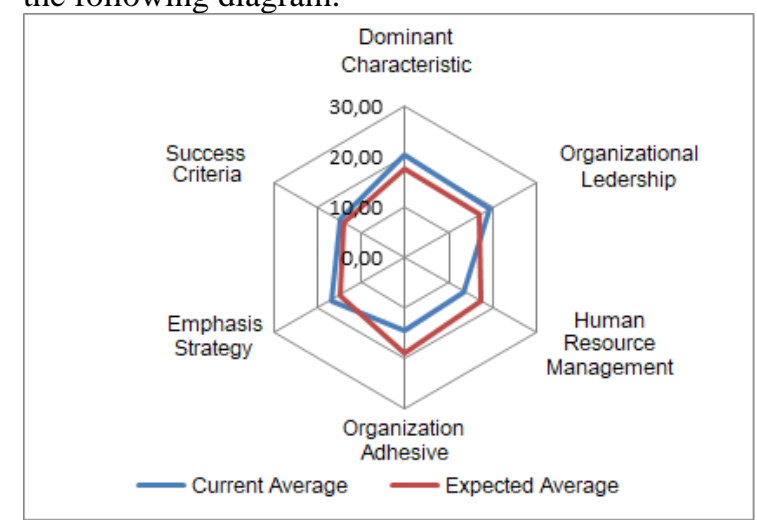

Figure 6 Scoring Result of the Communication Culture Value with the OCAI model
The results of the analysis of this study are in line with the opinion of experts, namely Januar Darmawan in his book "Sustainable Growth" written by (Andrias Harefa, 2008) which reveals that:

"Communication must be built based on top-down initiatives, both vertically and horizontally must be opened and direct, and have the character of increasing informal communication and reducing the formal portion. Communication in this organizational system must be able to run well, and for that, we cannot rely on communication processes from the bottom-up level. Bottom-up communication is more difficult than communication with a top-down initiative".

The results of this study are in line with research conducted by (Hidayat, 2012), entitled "Organizational Culture According to the Competing Value Framework at Sari Asih Islamic Hospital Tangerang" using analytic survey, that stated:

"Suggestions conveyed in this study include prioritizing strengthening clan culture that focuses on a sense of kinship and participation, building good communication between directors and employees".

\section{Competence}

The following table describes the questionnaire result on the competence culture sub-focus. Table 5 Scoring Result of the Competence Culture Value with the OCAI Model

\begin{tabular}{|l|l|l|l|l|l|}
\hline $\begin{array}{l}\text { Competence } \\
\text { Character }\end{array}$ & $\begin{array}{l}\text { Current } \\
\text { Score }\end{array}$ & $\begin{array}{l}\text { Expected } \\
\text { Score }\end{array}$ & $\begin{array}{l}\text { Average } \\
\text { Current } \\
\text { Score }\end{array}$ & $\begin{array}{l}\text { Average } \\
\text { Expected } \\
\text { Score }\end{array}$ & $\begin{array}{l}\text { Average } \\
\text { Deviation }\end{array}$ \\
\hline $\begin{array}{l}\text { Dominant } \\
\text { characteristics }\end{array}$ & 165,00 & 200,00 & 16,50 & 20,00 & 3,50 \\
\hline $\begin{array}{l}\text { Organisational } \\
\text { leadership }\end{array}$ & 145,00 & 170,00 & 14,50 & 17,00 & 2,50 \\
\hline $\begin{array}{l}\text { Human } \\
\text { resource } \\
\text { management }\end{array}$ & 140,00 & 175,00 & 14,00 & 17,50 & 3,50 \\
\hline $\begin{array}{l}\text { Organisational } \\
\text { adhesive }\end{array}$ & 145,00 & 160,00 & 14,50 & 16,00 & 1,50 \\
\hline $\begin{array}{l}\text { Strategic } \\
\text { emphasis }\end{array}$ & 210,00 & 150,00 & 21,00 & 15,00 & $-6,00$ \\
\hline $\begin{array}{l}\text { Success } \\
\text { criteria }\end{array}$ & 195,00 & 145,00 & 19,50 & 14,50 & $-5,00$ \\
\hline
\end{tabular}

Currently, the dominant competency value was the skill at the staff level. The informants wanted a shift in improving the dominant characteristic value form the current average score of 16,50 to an expected average of 20,00 . The average deviation of 3,50 indicated the need for other competence than skills, namely knowledge and attitude. The average leaders' competence was already qualified, but the staff level's competence must be improved.

Organizational leadership on competence culture had an average deviation of 2,50 with the current average score of 14,50. It also showed an expected value of 17,00 . In this case, the management had not been optimal in developing employee competencies. The 
average deviation value of 3,50 was indicating the need for employees' development program. This development program should be integrated. It should focus not only on hard skills' training but also on knowledge development, the coherence with the working field, attitudes that can foster initiative and innovation, and a sense of belonging to the company.

The organizational culture of competence with an average score currently 14,50 to an expected average of 16,00 and a deviation of 1,50 which wanted an increase in the intensity of mutual help and mutual understanding between departments, between colleagues but it must be as much as possible and maintained continuously and consistently. It can be seen from the leaders' expectancy that there was a desire for a significant reduction in the strategy's intensity of emphasis. In this case, it was intended to prioritize increasing competence through human resource management and through means such as various training and development programs that were more appreciative and togetherness in nature, and programs that can run consistently.

The strategy emphasis values were 21,00 on the current average score with an expected average of 15,00 , and the average deviation of $-6,00$. Like the strategic emphasis, on the success criteria of competence was seen the leaders' desire to reduce the intensity of continuous discussion about achieving goals and increasing competence through HR management by evaluating and measuring capacity first and continued by determining company goals. It could be seen from the current average score of 19,50 to the expected average of 14,50, an average deviation of $-5,00$.

The scoring and interpretation results of the subfocus of competence culture are as illustrated in the following diagram.

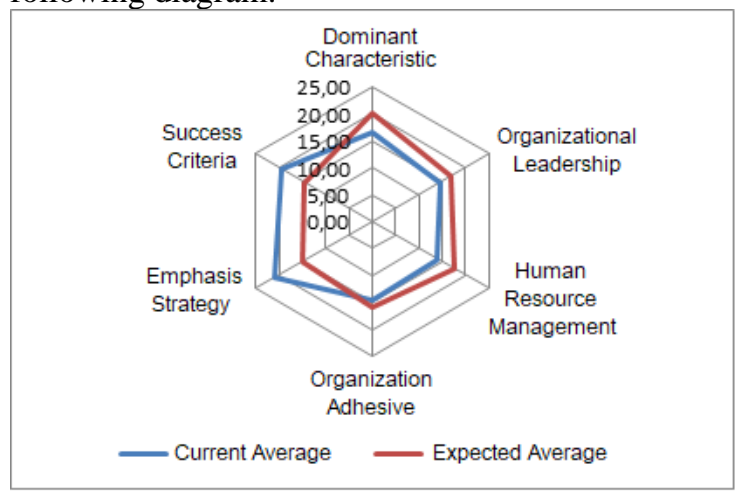

\section{Figure 7 Scoring Result of the Competence Culture Value with the OCAI model}

The results of the analysis of this study are in line with the opinion of experts, namely Januar Darmawan in his book "Sustainable Growth" written by (Andrias Harefa, 2008) which reveals that:

"In general, it could be said that competence is one of the building blocks of trust, competence is the ability to carry out and complete tasks and responsibilities today and for the future, and proactively seek and share knowledge in support of personal growth. Five basic competencies are considered critical: motivation, personal uniqueness, self-concept, knowledge, and skills. Knowledge and skills are visible and easily recognizable basic competencies that serve as a competency threshold. Meanwhile, motivation, personal uniqueness and self-concept are more hidden to differentiate competency. The task of management or the company's responsibility is to provide opportunities for employees to develop their competences sustainably so that employees are placed according to their competencies and competencies that have been successfully developed from time to time."

The results of this study are in line with previous research conducted by (Djastuti, 2016), entitled "Analysis of Organizational Culture Mapping Using Organizational Culture Assessment Instrument at PT Angkasa Pura I Ahmad Yani Airport Semarang ", that stated:

"The key to human resource management culture expects a culture of clan and adhocracy with a strategy to improve the development of the quality of human resources through regular and comprehensive training as well as creating a bonus appreciation system for HR that can create innovations for the company."

\section{Self-Control}

The following table describes the questionnaire result on the self-control culture sub-focus. 
Table 6 Scoring Result of the Self Control Culture Value with the OCAI Model

\begin{tabular}{|l|l|l|l|l|l|}
\hline $\begin{array}{l}\text { Self-Control } \\
\text { Character }\end{array}$ & $\begin{array}{l}\text { Current } \\
\text { Score }\end{array}$ & $\begin{array}{l}\text { Expected } \\
\text { Score }\end{array}$ & $\begin{array}{l}\text { Average } \\
\text { Current } \\
\text { Score }\end{array}$ & $\begin{array}{l}\text { Average } \\
\text { Expected } \\
\text { Score }\end{array}$ & $\begin{array}{l}\text { Average } \\
\text { Deviation }\end{array}$ \\
\hline $\begin{array}{l}\text { Dominant } \\
\text { characteristics }\end{array}$ & 210,00 & 160,00 & 21,00 & 16,00 & $-5,00$ \\
\hline $\begin{array}{l}\text { Organisational } \\
\text { leadership }\end{array}$ & 185,00 & 195,00 & 18,50 & 19,50 & 1,00 \\
\hline $\begin{array}{l}\text { Human } \\
\text { resource } \\
\text { management }\end{array}$ & 145,00 & 185,00 & 14,50 & 18,50 & 4,00 \\
\hline $\begin{array}{l}\text { Organisational } \\
\text { adhesive }\end{array}$ & 135,00 & 145,00 & 13,50 & 14,50 & 1,00 \\
\hline $\begin{array}{l}\text { Strategic } \\
\text { emphasis }\end{array}$ & 175,00 & 155,00 & 17,50 & 15,50 & $-2,00$ \\
\hline $\begin{array}{l}\text { Success } \\
\text { criteria }\end{array}$ & 150,00 & 160,00 & 15,00 & 16,00 & 1,00 \\
\hline
\end{tabular}

In the dominant characteristic, the leaders dominated the understanding and implementation of self-control culture. It expected that all levels of employees could understand and implement this self-control. The dominant characteristic's value declined from the current average score of 21,00 became 16,00 of the expected average, with average deviation was $-5,00$. The culture of self-control in leaders increased to be cascaded to every level below. In this regard, a good self-control leader will become a role model or role model for colleagues and subordinates.

Organisational leadership achieved a current average score of 18,50 to an expected average of 19,50, with an average deviation of 1,00 . In terms of managing employees, it expected that management would pay more attention to transmitting the cultural values of self-control to each level below. A working activity previously supervised by superiors was replaced by self-supervision by working according to standard systems and procedures.

Human resource management had a current average score of 14,50 to the expected average of 18,50, with an average deviation of 4,00. The cultural values of trust and motivation, which enhanced from selfcontrol would form harmonious cooperation in which the cooperative relationship could strengthen the relationship of all employees in the company.

The organizational adhesive got a current average score of 13,50 to the expected average of 14,50 , with an average deviation of 1,00 . The informants felt that it was more important to increase the intensity of management through human resource management, socialize and consistently implement quality standard systems and procedures, and socialize the understanding of self-control to achieve company goals. The strategy emphasis decreased from the current average score of 17,50 to the expected average of 15,50, and an average deviation of 2,00. The success criteria with the current average score of 15,00 to an expected average of 16,00 and a difference of 1,00 expected to increase slightly through the socialization of understanding the company's goals through self-control culture.

The scoring and interpretation results of the subfocus of self control culture are as illustrated in the following diagram.

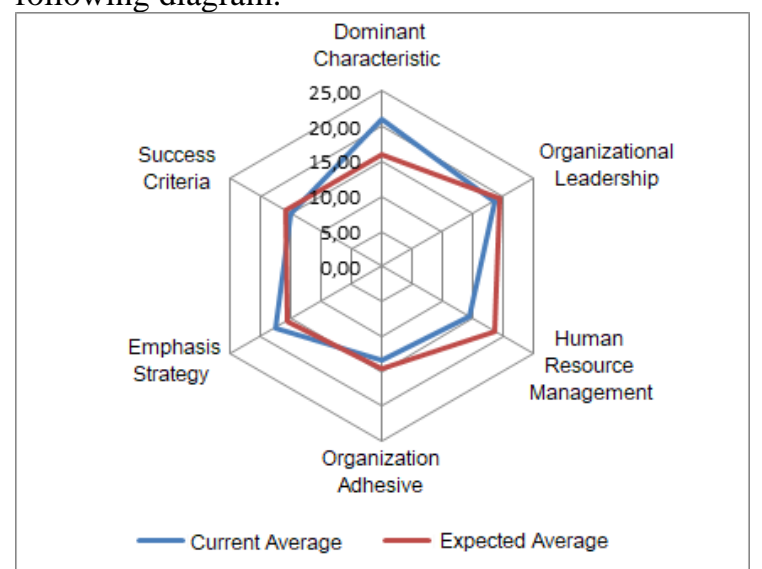

Figure 8 Scoring Result of the Self Control Culture Value with the OCAI model

The results of the analysis of this study are in line with the opinion of experts, namely Januar Darmawan in his book "The Prisma Way, The Practical Guide toward Soft Leadership" written by (Pauline Leander, 2015) which reveals that:

"In the ideal leadership concept, a good leader can build self-control within its members. It would be more beneficial to have a team that can build responsibility from within to keep promises, complete work on time, take the initiative, be creative, and innovate to achieve progress from day to day."

In another book, "Sustainable Growth" written by (Andrias Harefa, 2008), it also reveals that:

"Self-awareness to behave, act and work to achieve company goals is self-control. By carrying out this value, employees will show proactive behaviour (self-starter), driven by intrinsic motivation (selfmotivated), make decisions on time even though the 
rules are not/have not regulated (good judgment), show professional accountability, trustworthy, have integrity, and not be arrogant or boastful. Good selfcontrol can make people carry out self-discipline to comply with applicable regulations without being supervised by others, be responsible for doing work on time, distinguish between what is good and what is appropriate, and become a role model for colleagues work and subordinates."

The results of this research analysis are also in line with previous research conducted by (Putra, n.d. 2017), in the journal Organizational Culture Analysis that used the Organizational Culture Assessment Instrument Model at XYZ University, that:

"Organizational culture is closely related to the success of an organization. Based on the research results, all university elements want a culture in the future that develops is the culture of the Clan. Clan culture is closely related to tradition. The glue in the organization to the clan culture is loyalty, commitment and mutual trust."

\section{Conclusion}

\section{Communication}

Firstly, in the current corporate culture, communication is dominated by leaders. A leader's task is to send information more often, for directions than the executors or subordinates to convey information about the obstacles in carrying out their work. Secondly, the current organizational leadership culture in communicating is democratic, but it does not reflect subordinates' intense communication to superiors and the possibility of subordinates' embarrassment or fear. Thirdly, the communication culture in human resource management is still one way, more to management explaining or informing company regulations, company policies and job descriptions and responsibilities of employees. Fourthly, communication culture as the organisation's adhesive is currently running, but it needs to be improved, which reflected in informal communication forums, such as togetherness events. Fifthly, a communication culture to focus all elements on achieving the strategic mission has been running, even more, intense than communication in employee management and communication as the organisation's adhesive. Sixthly, the communication culture in determining the criteria for achieving existing goals is following the company's calendar or agenda, seen from routine meetings and evaluations in department head meetings, evaluation of action plans and monitoring of balanced scorecards.

\section{Competence}

Firstly, the current dominant competency value is still only a skill for the executive level, and the lack of knowledge and attitude values is applied. Secondly, on average, leaders' competence has already qualified, but the staff's competency level still must be improved. Thirdly, in managing employees, it is felt that they are not optimal in developing their employees' competence. Training and retraining do not reflect the existence of soft skill development programs, namely knowledge and attitude.

Fourthly, the strategy for achieving competence has not achieved the competency values of knowledge and attitude. It can be seen from the leaders' expectancy that there is a desire to reduce the intensity of the emphasis in the strategy, in this case, the intention is to prioritize competency improvement through human resource management and through different methods such as various training and development programs that are more collaborative. Fifthly, it can be seen from the leaders' expectancy that there is a desire to decrease the intensity of achieving goals' discussion rather than increasing competencies through human resource management and various training and development programs that are more collaborative.

\section{Self-Control}

Firstly, the culture of self-control, averagely, only understood and carried out by leaders, all levels of employees should also understand and implement self-control with different portion. Secondly, the selfcontrol value only understood by the leaders. Regarding this, the value should be implemented at each level. Moreover, leaders' attitude of self-control would become a role model for subordinates. Thirdly, management of employees by management regarding self-control's cultural value has not yet reached the staff level. Fourthly, the value of self-control is currently not optimal in bonding all elements; the relationship between departments is felt only between leaders who have closeness. Fifthly, the value of self-control regarding strategic emphasis has exercised by the management or leader level. It is necessary to cascade the implementation formulas to the lower level. It is more important to increase the intensity of management through human resource management, adequately and consistently implement quality standard (ISO) systems and procedures, and socialize the understanding of self-control to achieve company goals. Sixthly, the value of self-control to achieve its goals felt by only leaders who understand. It expected that the values of self-control culture could be cascaded on to subordinates to be understood.

\section{Recommendation}

Based on the analysis and conclusions, the authors convey recommendations to the company both strategically and operationally. Strategic advice is at the policy or regulatory level, while operational advice is at the Standard Operating Procedure (SOP) level.

\section{Communication}

Make an informal communication culture policy and reduce the formal portion, and the program must be consistent. When there is open \& direct, horizontal \& 
vertical communication, there will be a harmonious atmosphere between subordinates and superiors, among colleagues where when harmony created, employee performance will automatically increase efficiency and effectiveness, and finally, all strategic missions can run coherently with the goals that the company has set. To run these programs, the author recommends re-forming a bipartite cooperation institution regulated in the Manpower Act No. 13 of 2003. Bipartite discusses work discipline, occupational safety and health (K3) programs, productivity, normative provisions discuss working hours, overtime hours, shift work, and others), creating or re-evaluating policies or SOPs regarding communication culture. If necessary, it is also recommended to provide a suggestion box so that employees convey their aspirations without fear or embarrassment.

\section{Competence}

Knowledge \& skill is a fundamental competency that shows capacity, has a good capacity and is accompanied by a motivational attitude and selfconcept that will drive quality decisions. The task of management and company responsibility is to provide employees with opportunities to develop their competencies in a sustainable manner (Growing Competence). Thus, employees are placed according to their competencies and competencies that have been successfully developed from time to time. For the development of competencies other than skills, namely knowledge and attitude, it is recommended to make a PT Briscor Horizon policy to design various training and development programs and create learning forums that must be carried out consistently at all levels. Moreover, it is also suggested to review the SOP for training and development; whether it is coherence with the needs, it can be reviewed with one of the training evaluation's models, for example, the Kirk Patrict model.

\section{Self-Control}

Self-control is the opposite of command control, an old leadership style that applies inherent instructions and supervision, self-control adheres to the principle that people are willing to work optimal because their motivations drive them, not only because of wages and bonus prizes. It can happen when people are motivated to do what they love to do because that is their passion. Self-control in PT Briscor Horizon's culture is recommended to socialize the understanding of the values of self-control to the lowest level and according to the portion, and in managing employees so that management can know and evaluate the passions of each employee. It is also recommended to make SOPs regarding management (planning, implementation, and evaluation) of selfcontrol, especially regarding extracting employee passion.

\section{References}

1. Andrias Harefa. (2008). Sustainable Growth.

2. Arikunto, S. (2010). Prosedur Penelitian Ilmiah. In Rineka cipta, Jakarta.

3. Bungin, B. (2011). Metodologi Penelitian Kualitatif. In Rineka Cipta.

4. Cangara, H. (2002). Pengantar Ilmu Komunikasi (Cetakan Keempat). In Jakarta: PT Rajagrafindo Persada.

5. Chambers, D. W. (2005). Self-control. The Journal of the American College of Dentists. https://doi.org/10.1111/j.14678721.2009.01645.x

6. Chaplin, J. P. (2014). Kamus Lengkap Psikologi. Penerjemah. In Jakarta: PT Raja Grafindo Persada.

7. Cordell, A., Thompson, I., Cordell, A., \& Thompson, I. (2019). Communication Process. In The Procurement Models Handbook. https://doi.org/10.4324/9781351239509-4

8. Dean, E. (2017). Cultural competence. Nursing Standard (Royal College of Nursing (Great Britain) : 1987). https://doi.org/10.7748/ns.31.22.15.s16

9. Djastuti, M. D. S. C. \& I. (2016). Analysis of Organizational Culture Mapping Using Organizational Culture Assessment Instrument at PT Angkasa Pura I Ahmad Yani Airport Semarang.

10. Effendi, M. (2016). PARADIGMA PENELITIAN KOMUNIKASI. KOMUNIKA: Jurnal Dakwah Dan Komunikasi. https://doi.org/10.24090/komunika.v1i2.796

11. Hidayat. (2012). Organizational Culture According to the Competing Value Framework at Sari Asih Islamic Hospital Tangerang.

12. Le Deist, F. D., \& Winterton, J. (2005). What is competence? In Human Resource Development International. https://doi.org/10.1080/136788604200033822 7

13. M. Nur Ghufron \& Rini Risnawita S. (2014). Teori-Teori Psikologi. Yogyakarta: Ar-Ruzz Media.

14. MacLean, E. L., Hare, B., Nun, C. L., Addess, E., Amic, F., Anderson, R. C., Aureli, F., Baker, J. M., Bania, A. E., Barnard, A. M., Boogert, N. J., Brannon, E. M., Bray, E. E., Bray, J., Brent, L. J. N., Burkart, J. M., Call, J., Cantlo, J. F., Chek, L. G., ... Zhao, Y. (2014). The evolution of self-control. Proceedings of the National Academy of Sciences of the United States of America. https://doi.org/10.1073/pnas.1323533111

15. Marwansyah. (2012). Manajemen Sumber Daya Manusia. Manajemen Sumber Daya Manusia.

16. Nagy, T. F. (2005). Competence. In Journal of Aggression, Maltreatment and Trauma. https://doi.org/10.1300/J146v11n01_03 
17. Pauline Leander. (2015). The Prisma Way, The Practical Guide toward Soft Leadership.

18. Putra, I. A. G. S. (2017). Organizational Culture Assessment Instrument Model.

19. Sánchez-Cañizares, S. M., Ayuso Muñoz, M. Á., \& López-Guzmán, T. (2007). Organizational culture and intellectual capital: A new model. Journal of Intellectual Capital. https://doi.org/10.1108/14691930710774849

20. Sugiyono. (2013). Metodelogi Penelitian Manajemen. In Bandung. Alfabeta. 